konstatacje autorki dotyczące występowania w historii technologii komputerowej zagadnień związanych z piśmiennictwem i jego obiegiem w społeczeństwie oraz z komunikacją za pomocą słowa pisanego między ludźmi i między człowiekiem a komputerem. Świetnie ukazują one przenikanie się i splatanie w badaniach nad współczesną rzeczywistością komunikacyjną zainteresowań bibliologów, informatologów i historyków informatyki.

\author{
Barbara Sosińska-Kalata \\ Instytut Informacji Naukowej i Studiów Bibliologicznych \\ Uniwersytet Warszawski
}

Nadestano: 30.01.2014.

\title{
Władysław Marek Kolasa: Historiografia prasy polskiej (do 1918 roku) - naukometryczna analiza dyscypliny (1945-2009). Kraków: Wydaw. Nauk. Uniwersytetu Pedagogicznego, 2013, ss. 528 + CD. Seria „Prace Monograficzne” 678. ISSN 0239-6025. ISBN 978-83-7271-843-1
}

W swojej monografii Władysław Marek Kolasa poddał wieloaspektowej analizie bibliometrycznej dorobek badawczy i osiągnięcia historyków prasy polskiej z lat 1945-2009. Uwzględnił publikacje, w których omawiali oni stan i rozwój polskiej prasy od jej początków do 1918 r. Autor cały ten okres podzielił na dwa działy główne: $\mathrm{w}$ pierwszym $\mathrm{z}$ nich objął badaniami zbiór prac nad dawną prasą polską (tj. do 1864 r.), w drugim zaś - nad prasą doby popowstaniowej (1864-1918). Zastosował więc podział według okresów historycznych, dodatkowo osobno wydzielił prasę polską za granicą (którą następnie włączył do odpowiednich działów głównych), opracowania ogólne, historię radiofonii i telewizji, metodologię badań historycznoprasowych. W obrębie poszczególnych działów zastosował dalsze podziały, zgodnie ze specyfiką i zawartością działów głównych. W sumie książka składa się z trzech rozdziałów, dzielących się na podrozdziały. Pierwszy z nich szczegółowo objaśnia przyjęte przez autora założenia i metody badawcze, opis zasad budowy i zawartości opracowanej przez niego bazy danych (Indeks Cytowań Historiografii Mediów Polskich), która stała się podstawowym narzędziem do oceny analizowanej dyscypliny. Rozdział ten zawiera też hipotezy badawcze potwierdzone przez wstępne wyniki bibliometrycznej analizy zgromadzonego w bazie materiału. Dwa kolejne rozdziały łączą w sobie bardzo szczegółowe analizy stanu badań (piśmiennictwa) nad rozwojem polskiej prasy z wnikliwym obrazem historii prasy w całym omawianym okresie. Obszerne (29 stron) zakończenie pracy nie tylko zbiera wnioski wynikające z poprzednich rozdziałów, ale wprowadza też nowe ustalenia, związane z różnicami i podobieństwami w rozwoju badań nad prasą w obu omawianych przedziałach czasowych (do 1864 r. i po powstaniu styczniowym do końca I wojny światowej) oraz formułuje postulaty dotyczące podjęcia badań w obszarach słabo do tej pory rozpoznanych. Rozprawę uzupełnia bibliografia, która wyodrębnia prace metodologiczne (łączy tu metodologię badań bibliometrycznych, historycznych, prasoznawczych oraz uwzględnia prace z zakresu krytyki naukowej) oraz - w wyborze (ok. 600 pozycji) - opracowania z historii prasy polskiej wraz z dodatkowymi istotnymi danymi o każdej publikacji (oznaczenie jej przynależności do działu, liczba cytowań). Pełną bibliografię prac naukowych z zakresu historii prasy, liczącą 4553 pozycje, z których każda zawiera także ważne dane dodatkowe, dołączył autor na płycie CD. Rozprawę uzupełniają ponadto indeksy i wykazy: indeks uwzględnionych w pracy tytułów czasopism i gazet z lat 1501-1918; indeks osób wymienianych w tekście i przypisach dysertacji; spis tabel, wykresów, rysunków i map. Bardzo przydałby się również indeks przedmiotowy, gdyż harmonijnie połączyłby wielokrotnie poruszane w rozprawie wątki tematyczne, te same, choć odnoszące się do różnych okresów. 
Tematyka i sposób ujęcia problemu w dysertacji W. Kolasy na pewno zainteresuje przedstawicieli szeroko rozumianej humanistyki, przede wszystkim prasoznawców, historyków dziejów, naukoznawców, bibliologów, literaturoznawców i politologów. Ta interdyscyplinarność przedmiotowa i metodologiczna zaznaczona jest już w tytule dzieła. Główny cel badawczy, jakim jest systematyzacja i ocena dorobku nad poznaniem dziejów prasy polskiej, autor starał się zrealizować w pierwszym rzędzie za pomocą metod bibliometrii, nie odżegnując się jednak od metod stosowanych w innych naukach humanistycznych, przede wszystkim historii i prasoznawstwie. Traktowanie bibliometrii jako metody podstawowej spowodowało szereg komplikacji, z którymi W. Kolasa bardzo dobrze sobie poradził. Gdyby zawęził zastosowanie bibliometrii do tzw. bibliometrii prostej, ograniczającej się do wnioskowania na podstawie zbioru prac źródłowych (bieżących), nie miałby większych trudności $\mathrm{z}$ wyborem podstawy badawczej (materiału badawczego). Ponieważ jednak zamierzał wykorzystać analizę cytowań, a zdawał sobie sprawę z nikłej reprezentacji polskich publikacji w istniejących indeksach cytowań, samodzielnie opracował narzędzie badawcze, umożliwiające realizację zamierzonego celu. Przygotował się do tego niezwykle solidnie, rozpracowując szczegóły i warianty funkcjonowania znanych baz danych (SCI, SSCI, A\&HSCI, SCOPUS). W rezultacie w ciągu pięciu lat zbudował wspomniany już Indeks cytowań historiografii mediów polskich (ICHMP), który posłużył mu do wieloaspektowego wnioskowania o stanie i rozwoju historiografii prasy polskiej. Warto tu nadmienić, iż w odróżnieniu od filadelfijskich indeksów cytowań wyjściowym materiałem źródłowym stały się nie tylko czasopisma, ale także książki. Słusznie bowiem uznał autor, że to one w humanistyce odgrywają rolę pierwszorzędną. Kompletując materiał badawczy, dokonał mrówczej pracy, analizując literaturę przedmiotu zawartą w dysertacjach doktorskich (447) i rozprawach habilitacyjnych (87), dotyczących historii mediów. Opisy bibliograficzne publikacji zaczerpnął też z kilkudziesięciu bibliografii prasoznawczych, historycznych, bibliologicznych. Przy typowaniu tytułów czasopism, których zawartość rejestrowano w bazie, posłużył się rozkładem Bradforda, rozpoczynając od czasopism podstawowych, a kolejne dzieląc na grupy zawierające zbliżoną liczbę artykułów. W trosce o pełny obraz analizowanej dyscypliny słusznie autor wprowadził do bazy pewną liczbę publikacji pokrewnych (przede wszystkim prasoznawczych). Oczywistym dopełnieniem związków historiografii prasy z innymi dyscyplinami stała się analiza zawartych w bazie cytowań. W sumie, na użytek monografii, autor przeanalizował 15041 prac bieżących i 46162 cytowań. Tak szeroka podstawa badawcza, skonstruowane przez autora wskaźniki bibliometryczne i ich analiza pozwoliły na szereg konstatacji, uogólnień i ustaleń dotyczących właściwości piśmiennictwa z zakresu historii mediów, takich jak: wyłonienie grupy autorów podstawowych (ich produktywności i cytowalności), chronologicznego rozkładu publikacji i cytowań, czasu starzenia się publikacji, średniej liczby cytowań na publikację, względnej liczby prac cytowanych, zależności między rodzajem publikacji a jej cytowalnością, wpływu określonych rodzajów publikacji na stan dojrzałości dyscypliny.

Warto zaznaczyć, iż utworzony przez autora Indeks posłużył nie tylko do wnioskowania o rozwoju badań nad prasą, ale także do bardzo interesujących i wartościowych porównań z filadelfijskimi indeksami cytowań. Autor udowodnił w ten sposób, że nauki humanistyczne (na przykładzie historii) zachowują się w sposób zbliżony do niektórych nauk przyrodniczych (np. materiałoznawstwa, nie zaś tak, jak wynika to z analizy danych ujętych w humanistycznej części WoS (Arts \& Humanities Citation Index) (s. 30).

Rozwinięcie i uszczegółowienie wniosków, wynikających ze stanu badań nad historią mediów, W. Kolasa zawarł w dwóch zasadniczych rozdziałach, koncentrujących się na prasie polskiej do $1964 \mathrm{r}$. (Rozdz. 2.) i prasie polskiej do 1918 (Rozdz. 3.), o czym już wyżej wspomniałam. Oba okresy - dostrzegając ich specyfikę i odmienności - przeanalizował w podobny sposób: ukazał uwarunkowania i ogólne tendencje w badaniach prasy danego okresu, dokonał szczegółowej periodyzacji i systematyzacji badań w każdym z okresów, wyodrębnił prace podstawowe (klasyczne) dla poszczególnych okresów i przedstawił sylwetki ich autorów, omówił ważne ośrodki badań nad prasą, odniósł się do wpływu warunków geopolitycznych na rozwój prasy w badanych okresach. Brał również pod uwagę języki prasy (język 
polski na tle innych w różnych częściach kraju), ilościowy rozwój prasy, trwałość gazet i czasopism, ich częstotliwość. Autor nie tylko omawia i interpretuje stan badań nad prasą, ale wszędzie tam, gdzie to jest możliwe, uzupełnia dotychczasową wiedzę o prasie na podstawie zgromadzonych przez siebie danych bądź wykazów piśmiennictwa zamieszczanych w pracach innych autorów. Pozwala mu to na dostrzeżenie niedostatków dotychczasowych opracowań, zwłaszcza bibliograficznych, które nie raz pomijały ważne dla rozwoju prasy fakty. Dzięki zbudowanej przez siebie bazie mógł miarodajnie rozpoznać (a nawet ocenić) natężenie badań w różnych obszarach omawianej tematyki. Zastosowanie metod bibliometrii pozwoliło zaś na ukazanie skali zaniedbań, w tym przedziałów czasowych, w których ważny temat nie stał się przedmiotem publikacji lub potraktowany został powierzchownie.

Omówienie zawartości prasy z różnych punktów widzenia pozwoliło W. Kolasie także na ujęcie aspektów bibliologicznych, m.in.: wskazanie prac omawiających prasę jako nośnik informacji o instytucjach rozpowszechniających książkę czy też prac analizujących różne rodzaje i formy reklamy książki na łamach prasy, dokonanie krytycznej oceny stanu prac dokumentacyjnych i bibliograficznych. $\mathrm{Z}$ naukoznawczego punktu widzenia instruktywne są umieszczone w zakończeniu rozprawy porównania badań rozwoju prasy w obu podstawowych działach, które różnią się między sobą natężeniem prac badawczych, aktywnością i produktywnością uprawiających je uczonych, liczbą cytowanych dzieł klasycznych, liczbą cytowań przypadających na jedną publikację, liczbą prac syntetycznych i przyczynkarskich, liczbą powstałych prac doktorskich i habilitacyjnych, a co za tym idzie - wielkością wkładu w badania doktorantów i habilitantów. Łączy je natomiast nieprzerwane - choć o różnym natężeniu - zainteresowanie badaczy oboma działami. Do tak szczegółowego przedstawienia różnych cech i właściwości piśmiennictwa omawianej dyscypliny niewątpliwie przyczyniła się dogłębna i wieloaspektowa interpretacja wyników osiągniętych za pomocą wskaźników bibliometrycznych. Monografia nie przynosi więc - tak częstego przy ilościowym ujęciu problemu wyliczenia, ale dociekliwą i rzetelnie przeprowadzoną krytykę, która rysuje solidny obraz badań nad rozwojem prasy. To dużej wagi dokonanie naukowe, świadectwo głębokiej znajomości praw bibliometrii i umiejętności ich zastosowania.

W rozprawie znalazło się też trochę niedociągnięć zależnych i niezależnych od autora. Mimo efektownej szaty zewnętrznej i poprawnego ukształtowania edytorskiego tekstu, pozostało dość dużo „literówek", błędne odesłania do numerów tabel, błędnie podane przedziały czasowe. Brak też precyzji w używanej terminologii. SCI to jedna (najwcześniejsza) z serii indeksów cytowań, a nie ich ogólna nazwa, termin referencje w języku polskim oznacza zupełnie coś innego niż w angielskim, dlatego należy pozostać przy polskich określeniach: przypisy i cytowania (nawet jeśli niektóre instytucje i badacze używają niepoprawnego terminu). Nie wydaje się też trafnie użyta zbitka słowna „kompletne i reprezentatywne" (w odniesieniu do gromadzonego materiału): jeśli już, to w odwrotnej kolejności. Niepoprawne logicznie jest też rozróżnienie dwóch zbiorów: publikacji i cytowań (w tym przypadku cytowania to też publikacje). Warto byłoby też znaleźć trafniejsze określenie niż „prace jednostkowe” na publikacje poświęcone wąskim, szczegółowym zagadnieniom (przeciwstawne pracom syntetycznym). Mam też obawy co do poprawności zestawionych liczb publikacji w poszczególnych okresach. W badaniach bibliometrycznych rok zamykający jeden z przedziałów czasowych nie może być jednocześnie rokiem otwierającym przedział kolejny. Grozi to podwójnym liczeniem publikacji dotyczących owego roku, a co za tym idzie - zniekształceniem wyników. Autor nie informuje, czy i jak wybrnął z tego kłopotu przy ilościowej analizie piśmiennictwa w zazębiających się okresach historycznych (np. Tab. 8). Mam też obawy związane z czytelnością tytułu monografii. Wydaje się, że nie jest on dla wszystkich jednakowo zrozumiały, bez dodatkowego wgłębienia się w wyjaśnienia autora zawarte we „Wstępie” do pracy. Występują w nim bowiem - mogłoby się wydawać - dwie rozbieżne cezury czasowe. $\mathrm{Z}$ mojego punktu widzenia można było jako dopełnienie tytułu zasadniczego pozostawić jedynie: naukometryczna analiza dyscypliny bez podawania przedziału czasowego lub - jeśli autor uznał, że wszystko należy zmieścić na karcie tytułowej - uzupełnić odpowiednio tytuł: Historiografia prasy polskiej do 1918 roku w świetle piśmiennictwa z lat 1945-2009. Naukometryczna analiza dyscypliny. 
Reasumując dotychczasowe uwagi, opinie i oceny, należy raz jeszcze podkreślić niezaprzeczalne walory monografii W. Kolasy, do których należy: podjęcie zaniedbanego dotychczas obszaru badań; znaczenie podjętego problemu dla wielu specjalności humanistycznych; objęcie badaniami rozległego czasu; stworzenie oryginalnej koncepcji badań; utworzenie od podstaw obszernej bazy danych; wyjątkowa skrupulatność i wnikliwość badawcza, które doprowadziły do ukazania skali faktów - dotąd w rozwoju badań nad prasą niedostrzeganych, lub co najwyżej wyczuwanych intuicyjnie. Wyniki osiągnięte w badaniach wyróżniają się wszechstronnymi, dociekliwymi analizami, rzetelną erudycją i oryginalnością metodyczną. Dzięki naukoznawczej interpretacji zgromadzonego materiału badawczego autor nie tylko ocenił stan i rozwój historiografii prasy polskiej, ale zbudował model postępowania badawczego, który może być z powodzeniem wykorzystany w ocenie dorobku innych dyscyplin.

\author{
Marta Skalska-Zlat \\ Instytut Informacji Naukowej i Bibliotekoznawstwa \\ Uniwersytet Wrocławski
}

Nadestano: 5.06.2014.

\title{
Sebastian Dawid Kotuła: Komunikacja bibliologiczna wobec World Wide Web. Lublin: Wydaw. UMCS, 2013, ss. 170. ISBN 978-83-7784-443-4
}

Jednym z zawsze aktualnych zadań i nurtów działalności badawczej jest rozbudowywanie aparatu terminologicznego i dbałość o poprawność definicyjną wyrażeń wprowadzanych do języka naukowego, a także ich aktualność. Prace terminologiczne wiążą się nieodłącznie z kształtowaniem teorii danego obszaru badawczego, oba te procesy oddziałują na siebie wzajemnie. Niemożliwy wydaje się rozwój wiedzy teoretycznej bez odpowiedniego zasobu leksykalnego, którym można ją wyrazić, a z drugiej strony - nazwanie dostrzeganych, nowych zjawisk lub procesów jest punktem wyjścia do kolejnych przedsięwzięć eksploracyjnych.

Książka Sebastiana Dawida Kotuły pt. Komunikacja bibliologiczna wobec World Wide Web, przygotowana na podstawie rozprawy doktorskiej pod tym samym tytułem, obronionej w 2013 r. na Uniwersytecie Warszawskim, należy do tego właśnie nurtu badawczego. Praca składa się z trzech rozdziałów, obejmuje 386 pozycji bibliograficznych - w większości literatury polskiej, ale w znacznej części również anglojęzycznej.

Autor podjął udaną próbę skonfrontowania zaproponowanego w literaturze przedmiotu w latach 80. XX w. terminu „komunikacja bibliologiczna” oraz modelu tejże komunikacji, z wymogami współczesnego pola badawczego bibliologii i informatologii, $\mathrm{w}$ tym ze zmianami w procesach bibliologicznych, jakie wynikają z zastosowania nowoczesnych technologii informacyjnych. Swoje badania oparł w znaczącym stopniu na schemacie tejże komunikacji, opracowanym w Polsce przez Jerzego W. Zawiszę w 1980 r., ale proponowanym w tamtym czasie także przez badaczy anglojęzycznych. Odwołując się do okoliczności zewnętrznych wpływających na kształt i przebieg tego procesu, autor zaproponował znowelizowany, własny model komunikacji bibliologicznej oraz wprowadzenie terminów „cyfrowa komunikacja bibliologiczna” i „sieciowa komunikacja bibliologiczna” - z ich uzasadnieniem i egzemplifikacją.

W rozdziale pierwszym S. Kotuła przedstawił trzy czynniki zewnętrzne, kontekstowe, powodujące konieczność adaptacji modelu „tradycyjnej” komunikacji bibliologicznej do rzeczywistości wirtualnej oraz wprowadzenia nowych terminów („cyfrowa” i „sieciowa” komunikacja bibliologiczna). Zaliczył do nich: rozwój technologii teleinformatycznych, w tym szczególnie narzędzi społecznościowych 